\title{
«INDIVIDUAL CURRICULUM»AS A WAY OF PLANNING BY STUDENTS OF VOCATIONAL AND TECHNICAL EDUCATION OF THEIR EMPLOYMENT
}

\author{
Serhii Korol, Anna Zinchenko, Karina Hlushchenko
}

The article deals with the problem of student's employment in the specialty of graduation at vocational education institutions. Considering the plans of some students on relearning or developing new skills in courses or internships, they need awareness of right specialty to choose and job preferably to find after graduation. The paper considers the relevant issue of research and development of individual planning methods for vocational education students in terms of their employment. The emphasis is made on this factor impact for future employment, namely its impact on the individual professional orientation and career, which can be planned through an individual curriculum i.e. balanced life planning.

An individual curriculum is a set of activities that help taking responsibility for the future by combining educational activities at school, college, work and in general throughout the career. It determines the sequence, form and pace of mastering the educational program components, own experience and other successful experiences, methods and activities necessary for achievement of the main planning goal. An individual plan is important as planning efficiently turns knowledge into skills.

The study considered based upon the "Individual curriculum" method and auxiliary test methods: "Success motivation and failure fear (questionnaire by Rean A.O.)", a test to determine the motive for a profession choice - the method of professional self-determination by J. Holland.

The research was implemented on the basis of the Sumy Chemical-Technological Center for Vocational Education, consisting of two stages of online testing with further explanation to students and their individual curricula development.

The first research stage involved students' participation in an online quest, tests performance and obtaining explanations based on the methods of comprehensive interpretation.

The second research stage involved the method of "individual curriculum planning" based on a plan template according to the study year

Keywords: individual curriculum, vocational education, students, methodology, questionnaire, training, work, career, education, employment

How to cite:

Korol, S., Zinchenko, A., Hlushchenko, K. (2021). «Individual curriculum» as a way of planning by students of vocational and technical education of their employment. ScienceRise: Pedagogical Education, 6 (45), 18-23. doi: http://doi.org/10.15587/2519-4984.2021.248072

(C) The Author(s) 2021

This is an open access article under the Creative Commons CC BY license hydrate

\section{Introduction}

The issue of financial security is almost always of great relevance for people. Students of vocational education (hereinafter - students) have the opportunity to observe and analyze the family financial situation, namely parents, so they try planning training and employment. In addition to the fact that young people study, their needs for financing are increasing over time, but parents are not always able to meet all those. Thus, students start their careers with unofficial jobs, or not in their major field while still studying, that may have negative consequences.

According to the data, published in the information-analytical collection "Educational Reform: Results and Prospects" [1], as of January 1, 2019, vocational education institutions graduates amounted to 133.1 thousand of skilled workers, of whom 105 thousand students were employed and 28.1 thousand of graduates obtained the status of the unemployed. The results showed that students, remaining in their major specialty, accounted for $82.76 \%$ (comprising 109.58 thousand people out of 133.1 thousand qualified workers). However, the report didn't give the answer to the question "What do $17.24 \%$ do after graduation?". Of course, there are students who continued their studies in higher educational institutions after graduating. According to statistics, students of Luhansk, Ternopil regions and the city of Kyiv are the leaders in enrolling to HEIs. The largest percentage of graduates with free employment, i.e. not in the major field, is inherent to students of Sumy vocational education institutions $(24.88 \%-1294$ people), Luhansk (its appearance means that the majority of students with vocational education diploma entered a university or were employed in the sphere different to their major) (21.95 \% - 510 people) and Transcarpathian (19.36\% - 523 people) regions.

It should be highlighted, that the largest percentage of workers, employed not in their major, compared to other regions, comprises the students of the Sumy region. 
Only $3.29 \%$ out of $100 \%$ continue to study in higher education institutions [1].

These results allow us to assert the existence of a relevant problem for the Sumy region concerning employment of vocational education institutions students in their major. The paper found out that such students did not plan their own future career path in the process of studying. The general analysis of available data showed that unofficial employment or that not in the major field, the absence of pre-planning and ignorance of future actions may affect future employment and career. Therefore, the usage of the method of "individual curriculum" during the training period may contribute to achieving the main goal of training, namely the development and future employment.

\section{Literature Review}

Motivation is an important condition for learning and one of the determining factors for active task performance. In scientific works various aspects of study motivation and success stimulation of students are investigated, the empirical data, considering the dynamics of future specialists motivation as an important component of professional qualities structure, is analyzed, the notion and concept of motivation and motivational processes are revealed [2-4]; the prospects of the applicant individual educational trajectory realization, as well as individual curricula and life planning are determined [5-8].

The normative and legal documents, namely: the Law of Ukraine "On Education" dated 5.09.2017 No. 2145-VIII [9], Information and analytical collection "Educational Reform: Results and Prospects" consider the contingent of pupils, students of professional (vocational and technical) institutions, education and graduation and employment of students of vocational (professional) education institutions, their studying and graduation as well as the establishment of educational and practical centers [1]. Therefore, individual learning planning may turn out to be a motivator for successful learning and employment in the major.

\section{The aim and objectives of the study}

The aim of the study is to involves adaptation and testing the methodology of "Individual Curriculum" as a way of employment planning among students of the Sumy Chemical-Technological Center for Vocational Education.

To achieve the aim, the following objectives were set:

1) analyze and specify the essence of the study basic concepts;

2) characterize the target audience in terms of the needs of quality selection of working methods and analyze the age characteristics of vocational education institutions students;

3) organize a weekly online event for students of vocational education according to three methods: "Success Motivation and Failure Fear (Rean's questionnaire)"; a test on the motivation determination in future profession choice; J. Holland's method of professional selfdetermination;

4) implement the "Individual curriculum" method among students;
5) give conclusions and provide recommendations to the management, methodologist, students of educational institutions and students, majoring in "Social Work".

\section{Methods and Materials}

The study is based on the techniques of:

1) "Individual Curriculum" [10] (cooperation with an educational institution, the creation of objectively realistic and productive individual plans, based on the needs and experience of creating a previously made one (in association with a counselor or mentor, friends, family), the control of the future (all actions are planned in advance - the developed strategy));

2) a test "Success Motivation and Failure Fear (questionnaire by A. O. Rean)" (aimed at determining the students level of motivation, focus on success or failure) [11];

3) a questionnaire to determine the profession choice motives (analyzes the motives for students to choose the major, in which they are currently trained, either it was their personal choice (individually or socially important), or they were externally influenced (both positive and negative factors)) [12];

4) the method of professional self-determination by J. Holland (the ratio of aptitude, ability and intelligence for the best and most desirable profession choice) [13].

\section{Study Results and Discussion}

Educational activity is implemented by performing certain actions. During training, a person absorbs already developed knowledge or concepts, i.e. internal rethinking, and only then its practical usage. Thus, learning is a certain result of the interaction between teaching facilitators and students, i.e. the corresponding "unity of the cognition processes". But in order for this joint activity to be more effective, teaching facilitators need to take into account the interests of students, pay a significant part of attention to their needs, as well as create favorable conditions for learning at the institution [2].

The detailed study of the notion "needs" showed that it is "the requirement of someone or something, that demands satisfaction, so that the lack or deficiency in something in human life." T. Blank specifies and describes such needs as: the need for knowledge (interest and development), self-expression (acting with acquired knowledge/skills), self-esteem (striving for better results, self-improvement), social relations (communicating with others)) and security (certainty, stability) [10].

The vulnerability of students in vocational education institutions is a factor of great importance. According to the academic dictionary, the term "vulnerable" is interpreted as sensitive, receptive and easily susceptible to external stimuli [11]. Vulnerability is also seen as a state of human uncertainty and inability to take risks. Thus, we believe that qualities of vulnerability are common to students, as the concept includes signs of a sensitive, i.e. easily submissive, emotional, exciting person. Also, a vulnerable person is one who cannot cope with some life difficulties on his/her own. Students can be influenced by both internal and external factors, namely the financial capabilities of parents, 
friends and their guidance, in general, the economic situation of the state.

In 2021, a group of scientists from the Sumy State University studied "The impact of families' financial state on students' learning", involving three focus groups with students of vocational education at various educational institutions of the Sumy region (Sumy, Shostka, Konotop). The results of the study showed that students are irresponsible or uninterested in their studies (72\% have medium academic progress rate, $41 \%$ do not receive scholarships), some of them do not plan employment currently or will not work in the major field at all (50\% of students, aiming to work abroad, courses, retraining, odd jobs) because they do not like it (Shostka and Sumy), or they are not sure of their education importance, because the labor market is changing and their major may be irrelevant (Shostka). Just as some students want to relearn or gain new knowledge and skills in courses, internships, students need to understand what major course they should choose, what job they want to get after school. And so the issue of individual curriculum was of great relevance.

An important factor for future employment is the individual career orientation that could be planned with the help of an individual curriculum, i.e. the process of life planning.

An individual curriculum is "a set of activities that help in taking responsibility for the future by linking school, college, work activities and in general all of them throughout the career" [12]. This kind of a plan determines the sequence, form and pace of mastering educational program components, personal experience and other successful experiences, methods and activities necessary to achieve the main goal of planning [9]. An individual curriculum is important because it helps to turn knowledge into skills. It means the totality of all human knowledge and abilities, namely activity, cognitive, communicative and others [5].
Nowadays there is a popular concept of time planning, or time management, defined as a purposeful activity on achieving a quality result, a certain system of decisions. Thus, the decomposition of a multicomponent whole into parts, a clear formulation of decisions on how to take and integrate actions, comprise a systematic process of making managerial decisions about future activities [7].

The study involved the method of "Individual curriculum" and relevant auxiliary instruments, namely "Success Motivation and Failure Fear (questionnaire by A. O. Rean)", a test to determine the profession choice motives, the method of professional self-determination by J. Holland.

In the course of the research, implemented on the basis of the Sumy Chemical-Technological Center for Vocational Education, the online testing took place together with the introduction and study of features and structure of individual plans, followed by the students, creating individual curricula. The testing took place in two stages.

In the first stage of the study, the students took an online quest, completed test tasks and obtained information about themselves based on interpretations of the methods used. According to the results of the first test (Fig. 1), the students showed an unexpressed motivational pole. Therefore, it was concluded, that such respondents needed to work on improving their own level of motivation $(67 \%)$. However, it could be noted, that their results ranged from 11 to 12 points, which indicates an inactive tendency to success motivation as well as among other $(33 \%)$ students. That means, success motivation implies positive motivation, namely, a personal focus on a satisfying result. The basis of human activity is the hope for success and the need to succeed. Students with such a motivation are usually confident, responsible and proactive. They can be distinguished by their persistence and determination in their work.

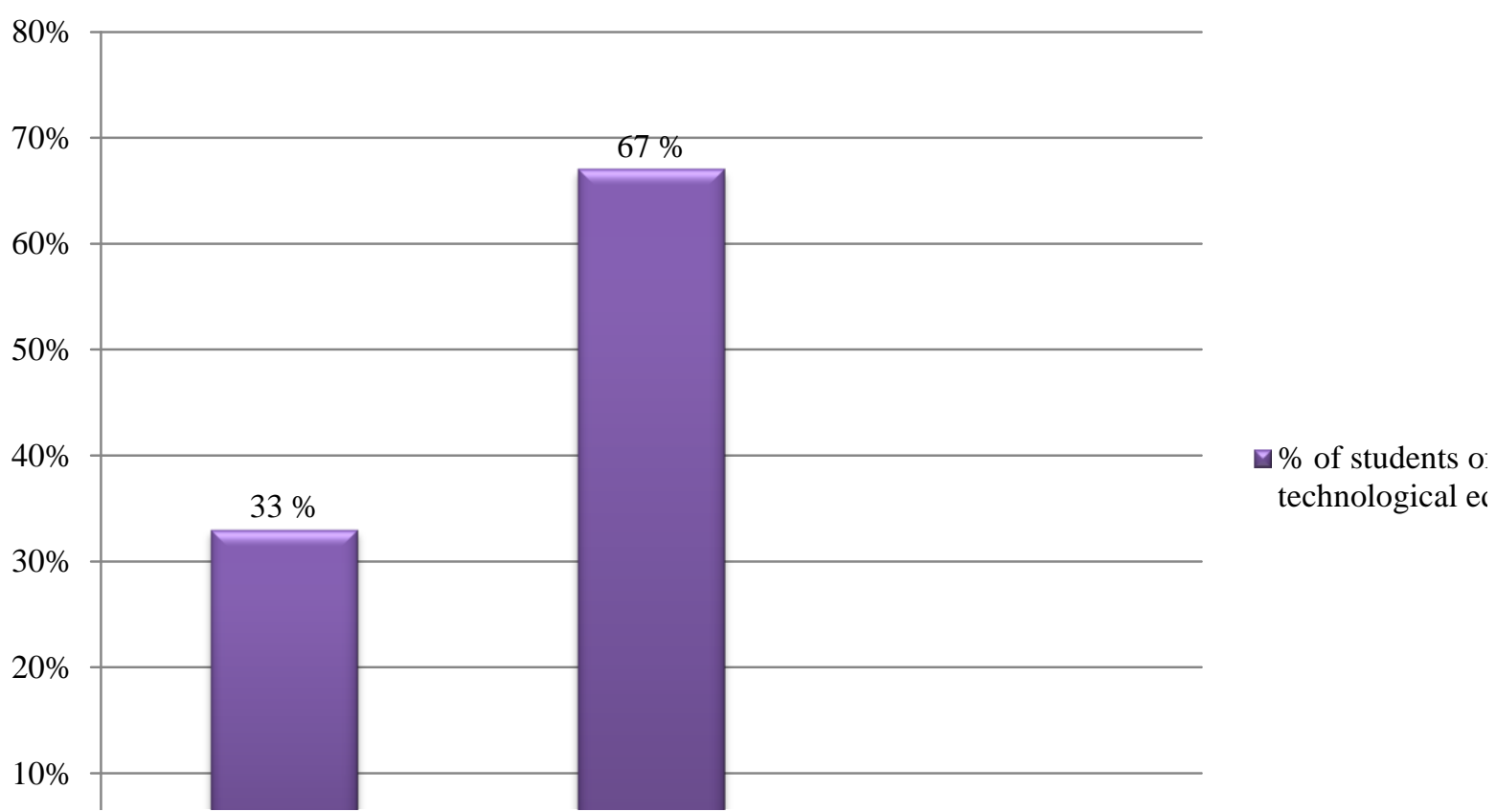

Fig. 1. Students' motivation assessment (Success Motivation and Failure Fear) (questionnaire by A. O. Rean) 
Analyzing the results of diagnosing the motive types of students for the major choice (the second method - Fig. 2), it was found out, that $100 \%$ of respondents made their choice based on their own internal motives (individually/socially significant). In the majority of students $(83 \%)$ according to the test results, the presence of formed socially significant motives was identified. This shows that they chose this major because of its relevance, necessary for people's lives and their existence. Internal socially significant motivation is based on the need to manage the process (e.g. production, enterprise). Regarding individual significance $(17 \%)$, the students, belonging to this group, chose independently the major they were mastering, as it was own choice. This was due to the fact that that occupation could bring pleasure, some creative enthusiasm and unloading, without being boring and as if "for the soul".

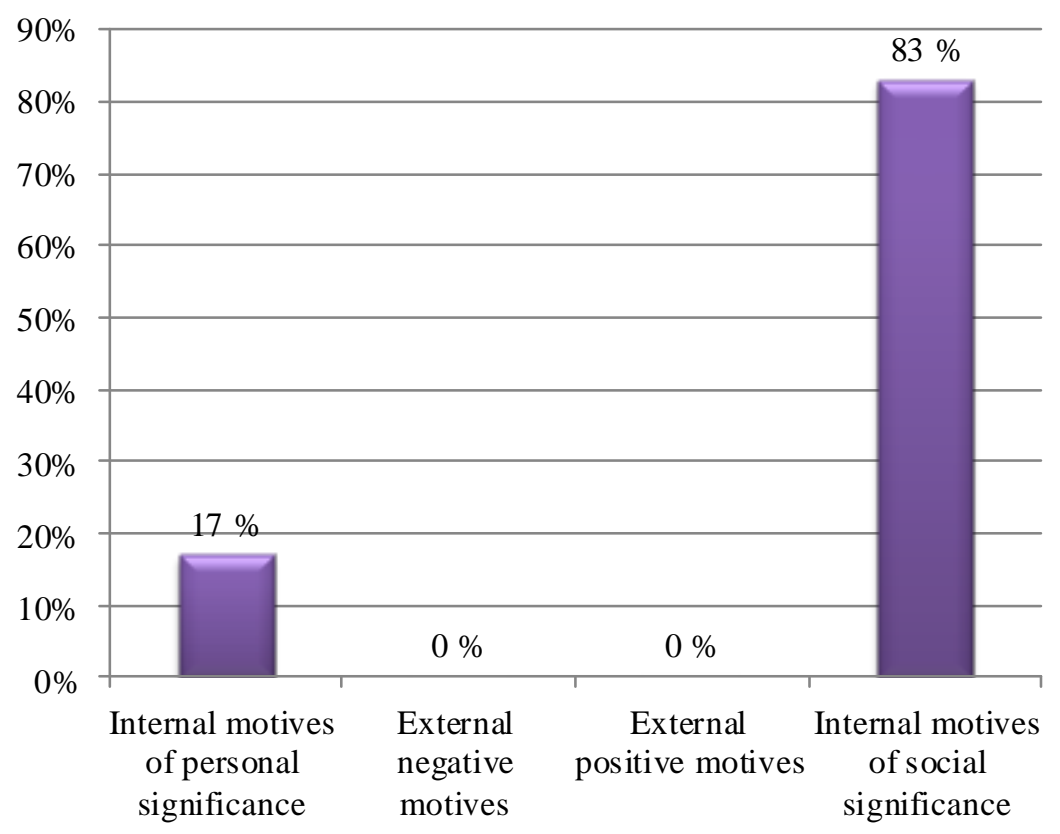

$\%$ of students of vocational and technological education institution

Fig. 2. The students' number assessment according to the motives of occupation choice (Test “Occupation choice motivation")

The third method analysis (Fig. 3), $50 \%$ of the students showed an enterprising type of professional selfexpression (show themselves clearly, spend energy on work, resourceful, but without a constant one-activity focus, lack of activity). $33 \%$ of the students comprised the realistic type of self-expression, focused on specific actions, that were constantly practically performed and being necessary. Students might prefer activities, requir- ing real-world conditions (i.e., a career, currently relevant and necessary). Intellectual $(17 \%)$ and social (17\%) types were characterized by: - constant analysis, development, learning, abstract thinking, original and creative decision-making; - high level of socialization, with highly developed communication skills, ability to quickly adapt to a new team and solve professional problems due to the developed ability to communicate.
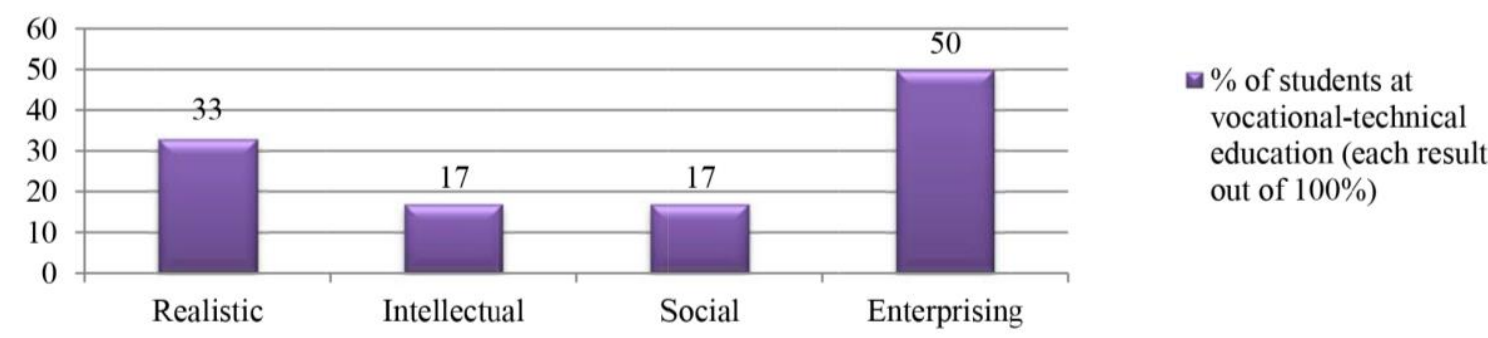
out of $100 \%)$

Fig. 3. Assessment of the professional self-expression type students may belong to (J. Holland's professional self-expression test)
The second stage involved the method of "Individual Curriculum" writing, providing a template for writing a plan according to the year of study using the prepared document. The students were sent recommendations for writing a curriculum and an individual learning plan for self-completion in accordance with the results of the methods. They were also provided with a template for the plan, possible options for action that could be entered and the results of their methods (i.e. indicators that they needed to reflect upon), as well as, perhaps, ask additional questions to the organizer of the study or teachers. The organizers noted what could be entered and 
what could be useful during the planning process. Only 6 students agreed to take part in this type of work, which also indicated a low level of motivation and interest among the students in their employment. Thus, the task was difficult for them to perform on their own, they had problems due to ignorance, namely what to enter in the template and what actions they could do now for future employment. Therefore, the students either didn't know how to use it or didn't want to. Also, from the answers to the question of drawing up an individual curriculum, it could be derived, that that type of work was unfamiliar and the process of writing was difficult. But the fact that the students tried to complete this task, and the implementation was more or less successful, indicated the continued adherence to the plan and completion of the following one according to the instructions of the methodology in order expand the skills and abilities in the future.

Thus, in the process of research it was possible to use practically all the tests, planned by the organizersresearchers, and to test the method of "Individual Curriculum" as a component of social support in employment among students of the Sumy Chemical-Technological Center for Vocational Education. The students liked analyzing their motives and interests in the occupation choice, they moved from the level of co-management to self-management by completing their own individual curricula.

The authors found the existence of objective limitations on the organization and practical implementation of the study: lack of students' motivation, which led to low involvement; quarantine circumstances - failure to connect the students on social networks, lack of communication, lack of control (most students were at home), time constraints.

The prospect of further research lies in the development of the "Individual Curriculum" and testing at educational institutions of III-IV levels of accreditation.

\section{Conclusions}

1. The paper gives theoretical argumentation and investigates the use of the method "Individual curriculum" as a way of planning own employment by students of vocational education institutions. The framework of the paper involved identification of the main theoretical aspects of the study, including a number of terms. It was investigated, that the concept of "individual curriculum" included a set of activities for employment planning during four years that turned out to be a complex and long process.

2. Some students of vocational education institutions have been "conditionally" classified as vulnerable. After all, this concept includes signs of a sensitive, easily submissive, emotional person, prone to high levels of excitement. The notion includes also a vulnerable person, who cannot cope with some difficulties in life on his/her own. Such students can be influenced by both internal and external factors, namely the financial capacities of parents, friends and their guidance, in general, the economic situation of the state.

3. The practical part of the study involved the following: the authors conducted three online tests, organized and conducted the process of writing students' own individual curricula. The testing was carried out in ac- cordance with the action plan, involving the method of "Individual curriculum" and relevant auxiliary instruments, namely "Success Motivation and Failure Fear (questionnaire by A. O. Rean)", the test to determine the profession choice motives, the method of professional self-determination by J. Holland. According to the results obtained, the students of vocational education institutions, participated in the testing, had no obvious motivation $(67 \%)$, but according to the key of the first method, this result might indicate an active unexpressed tendency to success motivation, as in the rest $33 \%$ of the students. Considering the types of students' motives on the major choice, it turned out that $100 \%$ of the respondents made their choice based on their own internal motives (individually or socially significant). Regarding the individual significance of the choice (17\%), the chosen specialty is the personal choice of a student, a profession to satisfy and unload. In case socially significant motives prevail $(83 \%)$ - the choice depended on the current relevance of the occupation, it's necessity for people's lives, their existence. Analyzing the third method, $50 \%$ of the students had an enterprising type of professional selfexpression (students clearly show themselves, spend energy on work, resourceful, but of no inherent concentration).

$33 \%$ of the students belonged to a realistic type of selfexpression, when representatives of this type focused on specific cases that were constantly practically performed and of the necessity. Intellectual $(17 \%)$ and social (17\%) types were characterized by the following points: the first - constant analysis, development, learning; the second - high level of socialization, developed communication skills.

4. The students were given recommendations for writing an individual curriculum and a plan for selfcompletion in accordance with the results of the methods.

Having tested these research methods, it could be noted, that the students liked to analyze their motives and interests in occupation choice, as they moved from the level of co-government to self-government by completing their own individual plans.

5. Analyzing the answers and results of methods, fulfilled by the students, it could be concluded, that the majority showed lack of motivation towards planning the future employment. Not many of the students in the group agreed to participate in that type of activity, which again indicated on their lack of interest and activity in the learning process. External factors that may have been affected should also be considered, such as quarantine restrictions, staying at home without access to social media, and technical problems with the online tools use. That type of work was previously unfamiliar to the students, the writing process was difficult, there were questions about filling and registration. However, the students tried to fulfill this task, and most of them succeeded. That suggested the conclusion, that the curriculum is needed to be followed as well as other techniques for expanding skills and capabilities in the future should be used. It would be useful for students of vocational education institutions to continue the implementation analysis of the previous and completion of subsequent individual curriculum according to the methodology instructions, with consideration to the year of study. Adherence to the plan and constant self- 
improvement could lead to positive consequences, namely successful employment in the major field or occupation, which students would like to get in the process of planning for the future (it is provided by the individual plan).

The recommendations for the Deputy Director for Training and Production Issues, for the Deputy Director for Training and Production Issues and the Methodist were elaborated in accordance with the research results, as well as for students of vocational education institutions and students, majoring in "Social Work" on the research related topics.

\section{References}

1. Osvitnia reforma: rezultaty ta perspektyvy (2019). Kyiv. Available at: https://mon.gov.ua/storage/app/media/Serpneva\% 20conferentcia/2019/Presentacii/Institut-zbirnik.pdf

2. Dokuchyna, T. O. (2011). Motyvatsiia navchannia yak zaporuka stymuliuvannia uchniv do dosiahnennia uspikhu. Pedahohichna osvita: teoriia i praktyka, 8, 32-37. Available at: http://nbuv.gov.ua/UJRN/znppo_2011_8_7

3. Nezhdanova, N. V. (2015). The empirical analysis of the dynamics of motivation of future specialists as an important component of the structure of their professional qualities. Visnyk Odeskoho natsionalnoho universytetu. Seriia: Psykholohiia, 20 (3 (1)), 71-81. Available at: http://nbuv.gov.ua/UJRN/Vonu_psi_2015_20_3\%281\%29_10

4. Kalinichenko, A. V. (2013). Motivation and motivational process: the nature and concept. Visnyk ekonomiky transportu i promyslovosti, 42, 417-420. Available at: http://nbuv.gov.ua/UJRN/Vetp_2013_42_72

5. Habenko, I. M. (2021). Doslidzhennia perspektyv realizatsii indyvidualnoi osvitnoi traiektorii zdobuvacha vyshchoi osvity. Teoriia i metodyka profesiinoi osvity, 2 (34), 37-40.

6. Bachke, C. C. (2015). Individualized Education Plans: What Characterizes the Research? Society, Integration, Education. Proceedings of the International Scientific Conference, 3, 31-44. doi: http://doi.org/10.17770/sie2015vol3.389

7. Kozlov, N. I. (2015). Planuvannia zhyttia. Psykholohis. Entsyklopediia praktychnoi psykholohii. Available at: http://psychologis.com.ua/planirovanie_zhizni.htm

8. Bogachkov, Y. M., Mylashenko, V. M., Ukhan, P. S., Sagadina, O. Y. (2018). ICT instruments for designing individual education path for high school students. Information Technologies and Learning Tools, 64 (2), 23-38. doi: http://doi.org/10.33407/itlt.v64i2.2164

9. Pro osvitu (2017). Zakon Ukrainy No. 2145-VIII. 05.09.2017. Available at: http://ru.osvita.ua/legislation/law/2231/

10. Individualized Learning Plan - About. U.S. Department of Labor. Available at: https://www.dol.gov/agencies/odep/ program-areas/individuals/youth/individualized-learning-plan

11. Motyvatsiia uspikhu ta boiazn nevdachi (opytuvalnyk Reana A. O.). Available at: http://testoteka.narod.ru/ms/1/08.html

12. Test «Motyvy vyboru profesii». Available at: https://www.bdut.org.ua/proforijentacija/motyvy-vyboru-profesiji/testmotyvy-vyboru-profesiji/

13. Test Dzh. Hollanda dlia vyznachennia profesiinykh typiv osobystosti. Available at: http://proforientator.info/?page_id=6016

Received date 14.09.2021

Accepted date 19.10.2021

Published date 30.11.2021

Sergii Korol, PhD, Associate Professor, Department of Psychology, Political Science and Sociocultural Technologies, Sumy State University, Rymskogo-Korsakova str., 2, Sumy, Ukraine, 40007

Anna Zinchenko, Assistant, Department of German Philology, Sumy State University, Rymskogo-Korsakova str., 2, Sumy, Ukraine, 40007

Karina Hlushchenko, Department of Psychology, Political Science and Sociocultural Technologies, Sumy State University, Rymskogo-Korsakova str., 2, Sumy, Ukraine, 40007

*Corresponding author: Sergii Korol,e-mail: korol.sumdu@gmail.com 